\title{
Risk and protective factors to prevent relapses of psychoactive substances users
}

\author{
Fatores de risco e proteção à recaída na percepção de usuários de substâncias psicoativas \\ Factores de riesgo y protección a la recaída en la percepción de usuarios de sustancias \\ psicoactivas
}

\author{
Meire Luci da Silva ${ }^{1}$, Camila Ferreira Guimarães ${ }^{1}$, Daiane Bernardoni Salles ${ }^{2}$
}

The objective of this study was to identify, in the perceptions of psychoactive substances users, protective and risk factors for relapses. Fifty users in treatment participated in this study in a therapeutic community in São Paulo, Brazil, in 2013. This is a qualitative study with the application of a self-administered questionnaire with closed questions and analysis through descriptive statistics. One identified as risk factors: lack of family support, family conflicts, negative feelings, social context, withdrawal from support groups, dissatisfaction with the treatment and financial difficulties. One highlighted as protective factors: religiosity, support groups, being the professional support one of the last support networks. One verified ambiguity of family and friends as a risk and protective factor. It is expected that the risk and protective factors identified may contribute to the prevention of relapse policies, enabling the enhancement of treatments focused on the recognition of protective factors, development of skills and coping strategies.

Descriptors: Substance-Related Disorders; Recurrence; Risk Factors; Protection.

Objetivo do estudo foi identificar, na percepção dos usuários de substâncias psicoativas, fatores de risco e proteção à recaída. Participaram 50 usuários em tratamento em uma Comunidade Terapêutica em São Paulo, Brasil, em 2013. Pesquisa quantitativa com aplicação de questionário de autopreenchimento com perguntas fechadas e análise através de estatística descritiva. Identificou-se como fatores de riscos: falta de apoio familiar, conflitos familiares, sentimentos negativos, contexto social, afastamento de grupos de apoio, insatisfação com tratamento e dificuldades financeiras. Destacou-se como fatores protetivos, religiosidade e grupos de apoio, sendo apoio profissional uma das últimas redes de apoio. Verificou-se ambiguidade da família e amigos enquanto fator de risco e proteção. Espera-se que fatores de risco e proteção identificados contribuam para políticas de prevenção à recaídas, possibilitando aprimoramento de tratamentos voltados ao reconhecimento de fatores de proteção, desenvolvimento de habilidades e estratégias de enfrentamento.

Descritores: Transtornos Relacionados ao Uso de Substâncias; Recidiva; Fatores de Risco; Proteção.

El objetivo de este estudio fue identificar, en la percepción de usuarios de sustancias psicoactivas, factores de riesgo y protección a la recaída. Participaron 50 usuarios en tratamiento en una Comunidad Terapéutica, en São Paulo, Brasil, en 2013. Investigación cuantitativa con cuestionarios auto administrado con preguntas cerradas y análisis a través de estadística descriptiva. Se identificaron como factores de riesgo: falta de apoyo familiar, conflictos familiares, sentimientos negativos, contexto social, abandono de grupos de apoyo, insatisfacción con tratamiento y dificultades financieras. Factores de protección destacados: religiosidad y grupos de apoyo, siendo el apoyo profesional una de las últimas redes de apoyo. Se constató ambigüedad de familia y amigos mientras factor de riesgo y protección. Se espera que factores de riesgos y protección identificados contribuyan para políticas de prevención a recaídas, permitiendo mejoramiento de tratamientos centrados en reconocimiento de factores de protección, desarrollo de habilidades y estrategias de afrontamiento.

Descriptores: Trastornos Relacionados con Sustancias; Recurrencia; Factores de Riesgo; Protección.

\footnotetext{
${ }^{1}$ Universidade Estadual Paulista Júlio de Mesquita Filho. Marília, SP, Brazil.
}

${ }^{2}$ Faculdade de Medicina de Marília. Marília, SP, Brazil. marilia.unesp.br 


\section{Introduction}

The use and abuse of psychoactive substances is a complex and dynamic phenomenon that affects the population of most countries, including Brazil. Currently, chemical dependency, and/or abusive and uncontrolled use of psychoactive substances is not only a serious medical problem, but also a public health, justice and social one. The abuse of psychoactive substances brings physical, psychological, emotional, behavioral, social and financial consequences to users, they affect directly and significantly not only the individual's quality of life, but also the family and society as a whole ${ }^{(1)}$. Substance abuse is considered of complex and interdisciplinary nature, and its treatment is dynamic, complicated and painful.

Data from the Drug Information Brazilian Center show that the main reasons that lead people to use drugs are to look for pleasure, decrease anxiety, tension, fears and relieve physical pain, also mentioned as a way to avoid the displeasure of drugs, easing symptoms of the withdrawal syndrome ${ }^{(2)}$.

Adherence to the drug treatment is guided by a number of challenges, and most of the time, this is interrupted by the return to drug use, characterizing relapse. Low adherence and lack of motivation for the treatment cause high rates of relapse, indicating a worrying scenario ${ }^{(3)}$.

The first days of a psychoactive substance user's treatment are more difficult due to withdrawal symptoms, and through the observation, monitoring and analysis of drug dependent people's relapses in the last years, it can be seen that stabilization of relapse episodes starts to happen approximately 90 days after the beginning of withdrawal. Relapse, with time, becomes a recurring factor in users' lives, because drug users who manage to remain abstinent after a single attempt to leave psychoactive substances are rare.
Relapses occur due to reasons connected to external and/or internal factors that users of psychoactive substances cannot handle and/or face. They are directly linked to the difficulty in interrelation with environmental situations, lack of coping skills, lack of self-control and often to the need of the positive effects of drugs. The withdrawal and lack of bond with post-discharge support services can be directly related to relapses because attending self-help groups or specialized services such as mental health services for alcohol and drugs strengthen coping skills of patients in order to face risky situations.

Relapses involve not only the possibility of choosing, but mainly the ability to avoid risk factors and the use of protective factors. However, for a dependent person to be able to avoid negative factors and events, he must first of all, not only identify them, but also be aware of their inability to deal with them. After the recognition and awareness that dependent people may increase their repertoire of skills and strategies to cope and/or anticipate relapse behaviors. However, it is possible that external elements are risk factors for relapse or protection.

There are several treatment modalities and their effectiveness is often questionable. The best known treatment modalities are: medication, with or without hospitalization; Non-drug treatments with admission; Non-drug treatments through the entry into self-help groups; cognitive behavioral therapies and harm reduction ${ }^{(4)}$. Most treatments are based on abstinence, so one of the important factors that helps in effective treatment is voluntary adhesion to the treatment by psychoactive substances users, because the "will to be treated" facilitates awareness of the disability and/or difficulty in dealing with a sum of emotional, subjective and social factors, that can induce them to relapse ${ }^{(5)}$.

Treatments for substance abuse are generally performed in community mental health services on 
alcohol and drugs, support groups and still in therapeutic communities. They are considered total institutions, because even with a voluntary hospitalization, total abstinence is defended, as well as rules regarding the routine and participation in full time groups, some of which also have religion associated to support the treatment.

It is believed that the ideal treatment would be the one that would address several factors, taking into account that drug addiction is a disease that aggregates biopsychosocial factors. Then one thinks of approaches that allow users of psychoactive substances the identification of risk factors and/or relapse signals and the development of skills and coping strategies, enabling them to control their recovery, abstinence maintenance and empowerment to reverse processes that can culminate in relapse. Motivation and voluntary adhesion are fundamental allies to an effective treatment, and motivation is a stimulus to continue the treatment which may be influenced not only by internal factors, but also external ones ${ }^{(6)}$.

Aiming at contributing to increase the effectiveness of the chemical addiction treatment and therefore decrease relapses in psychoactive substances users' lives, it is necessary to analyze the actual and specific situation of each group in order to identify risk and protective factors related to their life contexts. Therefore, the objective of this study was to identify, in the perception of users of psychoactive substances, risk and protective factors to relapse.

\section{Method}

This is a quantitative study. The sample was composed of 50 users of psychoactive substances in chemical dependency treatment in voluntary hospitalization regime. Research conducted in a therapeutic community located in São Paulo, which has approximately 60 inpatient beds. The people attended consist of members of various psychoactive substances, attended by health professionals, among them psycho- logists, occupational therapists and nurses, having also counselors specialized in addiction. In the period when the survey was conducted there were 58 patients, but only 50 accepted or had the required inclusion criteria.

The inclusion criteria were to be undergoing treatment, be abstinent for at least one month, be over 18 years old and accept to participate in the research. As exclusion criteria there was the presence of diagnoses of psychotic disorders and mental retardation.

A semi-structured questionnaire was created, about risk and protective factors, and it was based on standardized assessment tools, such as the ASSIST (Alcohol, Smoking and Substance Involvement Screening Test), CAGE (Cut-down, Annoyed, Eye-opener, Guilt), DUSI (Drug Use Screening Inventory) and AUDIT (Alcohol Use Disorders Identification Test), as well as information gathered in the literature about the subject. The questionnaire was composed of 11 closed questions, in which 6 were part of the adjustments I, area VI, questions 4-13 and area IX from DUSI, question 1 and 6 from ASSIST, question 10 from AUDIT and question 2 from CAGE. The other questions were prepared through the subject literature in order to contemplate the purpose of the study. The questionnaire was answered individually, working as a guide for data collection.

The questionnaires were applied individually in a place reserved in the institution by the researcher, who helped to read the questions, when necessary, avoiding any influence on the answers.

The data were analyzed through percentage and also by the occurrence of answers, and these data were interpreted, compiled and organized into charts to identify and visualize the results.

This study is part of a research project submitted for consideration and approved by the Research Ethics Committee of the Philosophy and Sciences College from the Universidade Estadual Paulista, under protocol 0524/2012. 


\section{Results}

The sample had 50 users of psychoactive substances, all men, with average age of 35 years old, median 34 years and standard deviation of \pm 10.02 years, average of treatment time of 5 months and 14 days. Participants had a family income of up to two minimum wages $(80.0 \%)$ and $2-4$ minimum wages (20.0\%). As for education they completed elementary school (90.0\%) and high school (10.0\%).

In relation to licit psychoactive substances there was a prevalence of alcohol (72.0\%) and tobacco (56.0\%). In relation to illegal drugs there was a predominant use of cocaine and/or crack (70.0\%), followed by cannabis (32.0\%) (Table 1). Highlighting that on this issue, individuals could choose more than one option, with the percentage calculated by number of occurrences

Table 1 - Types of psychoactive substances consumed

\begin{tabular}{lc}
\hline $\begin{array}{l}\text { Types of psychoactive substances } \\
\text { consumed }\end{array}$ & $\begin{array}{c}\text { Users numbers } \\
\text { (\%) }\end{array}$ \\
\hline Alcohol & $36(72.0)$ \\
Cocaine/Crack & $35(70.0)$ \\
Tobacco & $28(56.0)$ \\
Marijuana & $16(32.0)$ \\
Inhalants & $10(20.0)$ \\
Amphetamines/Ecstasy & $4(8.0)$ \\
Hallucinogens & $2(4.0)$ \\
\hline
\end{tabular}

Family configuration was identified as united (40.0\%), as opposed to little united and disunited family $(60.0 \%)$. This result can be confirmed by the responses related to family life, where there was a prevalence of family life between difficult and terrible (58.0\%).

Among the reasons that could lead to relapse one highlighted: frustration (46.0\%), family problems $(36,0 \%)$ and fatigue $(34.0 \%)$ Feelings that could in- duce to relapse were mentioned: frustration (50.0\%), anxiety (48.0\%), anger (48.0\%), fear (48.0\%) and guilt (44.0\%). On both issues, individuals could choose more than one answer choice, with the percentage calculated by number of occurrences (Table 2).

Table 2 - Feelings identified as motivators of relapse

\begin{tabular}{lc}
\hline Motivating feelings & $\mathbf{n}(\%)$ \\
\hline Frustration & $25(50.0)$ \\
Anxiety & $24(48.0)$ \\
Anger & $24(48.0)$ \\
Fear & $24(48.0)$ \\
Guilt & $22(44.0)$ \\
Obsession & $21(42.0)$ \\
Solitude & $21(42.0)$ \\
Joy & $18(36.0)$ \\
Sadness & $18(36.0)$ \\
Others & $8(4.0)$ \\
\hline
\end{tabular}

In relation to situations that could lead to relapse one mentioned family conflicts (44.0\%), party invitations (44.0\%) and prejudice (12.0\%) (Table 3).

Table 3 - Risk situations to relapse, according to psychoactive substance users

\begin{tabular}{lc}
\hline Situations & n (\%) \\
\hline Family conflicts & $22(44.0)$ \\
Invitation to parties & $22(44.0)$ \\
Environment someone lives & $15(30.0)$ \\
Job Loss & $11(22.0)$ \\
Difficulties/Sexual problems & $11(22.0)$ \\
Drugs offer & $10(20.0)$ \\
Prejudice & $6(12.0)$ \\
\hline
\end{tabular}

As places that favor the return to the use of drugs one pointed out: streets (32\%), parties (28\%), bars (28\%), home (18\%) and work (18\%) being the school the least mentioned place (04\%) (Table 4). 
Table 4 - Places that can lead to relapse according to

\begin{tabular}{lc}
\hline users & \\
\hline Places & Users $\mathbf{n}(\%)$ \\
\hline Streets & $16(32,0)$ \\
Parties & $14(28,0)$ \\
Bars & $14(28,0)$ \\
Home & $9(18,0)$ \\
Work & $9(18,0)$ \\
Others & $4(8,0)$ \\
School & $2(4,0)$ \\
\hline
\end{tabular}

Companies that lead to relapse were identified, friends from the time they used and/or other users (80.0\%), relationship partner (10.0\%) and unknown people (8.0\%). As important aspects for treatment efficacy one pointed out willpower (40.0\%), exchange of experiences with other drug users $(30.0 \%)$ and professional support (22.0\%).

Concerning the types of support for relapses prevention one mentioned religiosity $(74.0 \%)$, support groups (70.0\%), family support (54.0\%), work (48\%), professional support (30.0\%). In this question drug dependent people could tick more than one option.

\section{Discussion}

Alcohol was the psychoactive substance with higher prevalence of consumption (72.0\%). It is believed that one of the factors that help the high consumption of this substance is the fact that it is legal and therefore easily accessible. The psychoactive substances of illicit nature most often mentioned were cocaine and its derivatives $(70.0 \%)$ and marijuana $(32.0 \%)$. It is pointed out that $09.0 \%$ of the population presents abuse and/or harmful alcohol consumption, being $03,0 \%$ characterized as dependent. They state that $1.2 \%$ are dependent on marijuana and that the crack phenomenon has increased exponentially in numbers every year ${ }^{(7)}$.

Families were identified not only as a risk fac- tor for relapse, but also as a protective factor, and this ambiguity is pointed out in other studies ${ }^{(8)}$. Families can be considered a risk factor for relapse, because due to lack of information and understanding and due to wear related to the consequences of the frequent use of psychoactive substances by an addicted person, it has a low tolerance, culminating in a difficulty of accepting addiction as a disease. Misinformation and family unpreparedness cause the absence of support for drug dependent people, for the maintenance of abstinence of psychoactive substances and they also often cause lack of encouragement to look for treatment.

Family structure was indicated as little united and disunited (60\%), and family life as difficult and/ or terrible $(58.0 \%)$, thus showing the prevalence of fragile and ill family structures weakened by chemical dependency. Family dysfunction, permeated by family conflicts $(36.0 \%)$ was shown as a risk factor for relapse. This factor, together with low family income can justify the absence of clear rules for the use of psychoactive substances, causing in the future an increased risk of abuse ${ }^{(9)}$.

Family conflicts can lead to prejudice, fights, arguments and pressure on users of psychoactive substances, who usually finds in drugs a way of distancing and escape from these situations ${ }^{(10)}$. Results point to the need of a conscious and structured family, prepared for the development of management skills to deal with users' behaviors, development and consolidation of the most significant emotional ties and trust relationships between drug dependent people and their family members. Families may no longer be characterized as a risk factor, but they should be considered as a protective factor for relapse.

Substance abuse affects emotionally not only users of psychoactive substances, but also their families. Negative emotions are part of our daily routine, but when they are not properly dealt with, they can cause inappropriate behavior. In the case of psychoactive substance users, frustration, anxiety and anger were the main negative emotions identified as risk factor for relapse, corroborating studies conduc- 
ted ${ }^{(11-12)}$. Difficulty in dealing with the frustration was mentioned as the main reason to return to drug use. Factors such as altered mood, difficulties in decision-making and planning activities and negative feelings when given to oneself, associated with the pleasure transmitted by psychoactive substances favor relapse.

Situations related to invitations to parties (44.0\%) and parties $(28.0 \%)$ as relapse risky places are justified by the ease of access to psychoactive substances in this environment and also by the need for social inclusion in this context, since the use of the substance provides, even momentarily, feelings of well-being, joy, pleasure and euphoria ${ }^{(13)}$. One might think at parties even in a broader sense, because in our country, parties in general are linked to alcohol use, so it does not restrict these invitations only to friends who use drugs but also to the person's nuclear family. Invitations to parties may have a significant expression of the responses, since it involves several levels of users' acquaintances.

Streets, as an environment that permeates the idea of unlimited freedom, was reported for the main place of risk to relapse, a fact explained by the easy access to drugs, lack of rules and limits and, reunion and socializing with other users. Schools as a place that can provide return to use drugs had a low number of responses, because the sample consisted of individuals with an average age of 35 years old and therefore outside the school age. Low educational level may be associated with impaired family financial condition. Most of the sample has low family income, which may indicate greater illness of this family structure, which is to manage everyday situations, often without any professional help.

Going to places where psychoactive substances are present will provide dependent people not only visual contact with the substance, but also memories, raising an uncontrollable urge to use drugs and a possible loss of control, culminating in relapse.

Friends who use drugs and/or other users were identified as the main people that favor relapse. It is believed that friends from the "active" time are a bad influence, because they usually don't know the proble$\mathrm{ms}$ of the disease and facilitate and encourage users undergoing treatment to return to substance use.

Pressure of friends is mentioned as one of the major risk factors that favor relapse $\mathrm{e}^{(14)}$, because friends who are also users of psychoactive substances are harmful influences, since most of the time, they offer the psychoactive substance insistently and the person in treatment, in need of social approval, returns to drug use. Social pressure can be direct or indirect, through examples of other users such as alcoholic family member, exposure to objects, places and situations of use ${ }^{(12)}$.

As aspects that contribute to an effective treatment, there was the prevalence of self-will $(40.0 \%)$, followed by the exchange of experiences with other users (30.0\%) and professional support (22.0\%).

Religiosity was mentioned as the main support network for prevention of relapses, confirming results shown by some authors ${ }^{(14-16)}$, who believe that the practice of religion helps in promoting faith, providing support to deal with adversity, pain and suffering experiences, besides offering encouragement for healthy habits, enabling changes in ethical, cultural and behavioral aspects in relation to health, and consequently the improvement in quality of life ${ }^{(17)}$. Religiosity not only helps in the treatment process, but it is also a means to look for comfort, strength and meaning to life, besides providing welfare, which was previously achieved by the use of psychoactive substances, being relapse protection factor ${ }^{(18)}$.

Religiosity helps in the treatment of psychoactive substance users, as it enables an increase in optimism, improved self-esteem, decreased anxiety and perception of social support, helping to restructure a new group of friends ${ }^{(14)}$.

Support Groups were mentioned as a protective factor, because besides providing emotional support, they also have information and guidance character, assisting the user to cope and deal with risk factors. 
Support groups help in alleviating feelings of loneliness, social isolation, enabling exchange of experience and reflection ${ }^{(19)}$. It is an environment that allows the sharing of experiences and feelings, without fear, beyond the comprehension of other users of psychoactive substances.

Families were mentioned as a support network and therefore, a protective factor to relapse, in contrast to previous results mentioning the family as a factor risk, thereby increasing its ambiguity during the treatment process. Families as a protective factor can stimulate healthy behaviors and be a source of support, by demonstrating positive and protective feelings ${ }^{(9)}$.

Good family relationships, good communication, support, affection and encouragement for social reintegration collaborate for a better quality of life. Participation and family support during treatment can contribute significantly to the development and achievement of goals, success of treatment and consequently restructuring of lifestyle and changes in users' behavior ${ }^{(8)}$.

The families' difficulties in dealing with the problems arising from the addiction can be minimized by specific therapeutic monitoring, giving them emotional support and promoting the development of skills to manage and cope with risk situations to relapse, experienced by them together with users of psychoactive substances.

Health professionals and networks services specialized in drug treatment are considered a reference not only in the treatment but also in the prevention and maintenance of relapses, however in this study, the professional support was the last support network mentioned, thus pointing to the difficulty in the adhesion and participation of users of psychoactive substances to the treatment. This result leads one not only to question a possible fragility of health professionals, as to their professional training concerning welcoming and interventions to users, but it also denounces accessibility barriers in health institutions, and these barriers can be justified by characteristics of an unwelcoming and/or stigmatizing service, or even in a delay in the treatment due to a high demand, pointing to a system of deficient health policies. It is highlighted the importance of creating care networks focused on the development and implementation of intersectoral actions that favor the psychosocial rehabilitation of these individuals ${ }^{(14)}$.

\section{Conclusion}

The results allowed the identification of relapse risk factors, such as the inability due to family conflicts and negative feelings, and street parties as places that enable the use of psychoactive substances. Other evidenced risk factors are directly related to the social context, routine and people close to them who also make use of psychoactive substances.

Religiosity, followed by support groups and exchange of experiences with other users were mentioned as protective factors. Professional support was one of the last support networks mentioned by the users of psychoactive substances. This result highlights the need for research studies to investigate this fact, since professionals and services should be a reference for abstinence maintenance. Results showed ambiguity about families not only as a risk factor, but also as protection.

As a study limitation one highlights the fact that the research place was a therapeutic community that is linked to religious factors, which may interfere with the support network most mentioned by participants. It is important to develop studies with populations of various services, for a heterogeneous overview of the perception of drug dependent people about risk and protective factors.

It is expected to offer subsidies for the development and improvement of care policies to users of psychoactive substances, focused on relapse prevention, continuing education programs to professionals from the area, aiming to improve their understanding 
about the process of addiction and its implications in the quality of life, not only of the drug dependent people, but also on their social network, thus enabling interventions focused on the recognition of protective factors such as skill and coping strategies to maintain abstinence.

\section{Collaborations}

Silva ML contributed to the design of the research question until the development of the original article. Guimarães CF and Salles DB performed the literature research, collection and analysis of data, as well as the development of the original article.

\section{References}

1. Pratta EMM, Santos MAD. O processo saúdedoença e a dependência química: interfaces e evolução. Psic Teor Pesq. 2009; 25(2):203-11.

2. Secretaria Nacional de Políticas sobre Drogas, \& Centro Brasileiro de Informações sobre Drogas Psicotrópicas. VI Levantamento nacional sobre o consumo de drogas psicotrópicas entre estudantes do ensino fundamental e médio das redes pública e privada de ensino nas 27 capitais brasileiras. São Paulo: Secretaria Nacional de Políticas sobre Drogas; 2010.

3. Sousa PF, Ribeiro LCM, Melo JRF, Maciel SC, O MX. Dependentes químicos em tratamento: um estudo sobre a motivação para mudança. Temas Psicol. 2013; 21(1):259-68.

4. Ribeiro CT, Fernandes AH. Tratamentos para usuários de drogas: possibilidades, desafios e limites da articulação entre as propostas da redução de danos e da psicanálise. Anal Rev Psicanál. [periódico na internet]. 2013 [citado 2014 out 6]; 1(2):33-58. Disponível em: http:// www.seer.ufsj.edu.br/index.php/analytica/ article/view/372/405
5. Alves VS. Modelos de atenção à saúde de usuários de álcool e outras drogas: discursos políticos, saberes e práticas. Cad Saúde Pública. 2009; 25(11):2309-19.

6. Scaduto AA, Barbieri V. 0 discurso sobre a adesão de adolescentes ao tratamento da dependência química em uma instituição de saúde pública. Ciênc Saúde Coletiva. 2009; 14(2):605-14.

7. Alves VS, Lima IMSO. Health care to the addicts of alcohol and other drugs in Brazil: convergence between public health and human rights. Rev Direito Sanit. 2013; 13(3):9-32.

8. Xavier M, Rodrigues P, Silva M. A percepção da família no tratamento e suporte de dependentes químicos. Encontr Rev Psico. 2014; 17(26):99110.

9. Lemos VA, Antunes HKM, Baptista MN, Tufik S, Mello MT, Formigoni MLOS. Low family support perception: a 'social marker' of substance dependence? Rev Bras Psiquiatr. 2012; 34(1):52-9.

10. Landre M. Drogas e álcool - prevenção e tratamento. Campinas: Komedi; 2008.

11. Carvalho FRM, Brusamarello T, Guimarães AN, Paes MR, Maftum MA. Causes of relapse and search for treatment reported by drug users in a rehabilitation unit. Colomb Med. 2011; 42(1):5762.

12. Hendershot CS, Witkiewitz K, George WH, Marlatt GA. Relapse prevention for addictive behaviors. Subst Abuse Treat Prev Policy. 2011; 6:6-17.

13. Pratta EMM, Santos MA. Fatores de risco para o uso na vida e no ano de álcool entre adolescentes do ensino médio. SMAD, Rev Eletr Saúde Ment Álcool Drog [periódico na internet]. 2013 [citado 2014 out 6]; 9(1):18-24. Disponível em: http:// www.revistas.usp.br/smad/article/view/77410

14. Cavalcante LP, Falcão RST, Lima HP, Marinho AM, Macedo JQ, Braga VAB. Social support net for chemically dependents: ecomap as instrumental in health assistance. Rev Rene. 2012; 13(2):32131. 
15. Marlatt GA, Donovan DM. Prevenção da recaída: Estratégias de manutenção no tratamento de comportamentos aditivos. Porto Alegre: Artmed; 2009.

16. Secretaria Nacional de Políticas sobre Drogas. Fé na prevenção: prevenção ao uso de drogas em instituições religiosas e movimentos afins. Curso à distância. Brasília: Secretaria Nacional de Políticas sobre Drogas; 2009.

17. Lucchetti G, Koenig HG, Pinsky I, Laranjeira R, Vallada H. Religious beliefs and alcohol control policies: a Brazilian nationwide study. Rev Bras Psiquiatr. 2014; 36(1):4-10.

18. Al-Omari H, Hamed R, Tariah HA. The role of religion in the recovery from alcohol and substance abuse among Jordanian adults. J Relig Health. 2014; 1(1):1-10.

19. Alvarez SQ, Gomes GC, Oliveira AMN, Xavier DM. Grupo de apoio/suporte como estratégia de cuidado: importância para familiares de usuários de drogas. Rev Gaúcha Enferm. 2012; 33(2):1028. 